\title{
VESPASIAN'S APOTHEOSIS
}

Andrew B. Gallia*

In the study of the divinization of Roman emperors, a great deal depends upon the sequence of events. According to the model of consecratio proposed by Bickermann, apotheosis was supposed to be accomplished during the deceased emperor's public funeral, after which the senate acknowledged what had transpired by decreeing appropriate honours for the new divus. ${ }^{1}$ Contradictory evidence has turned up in the Fasti Ostienses, however, which seem to indicate that both Marciana and Faustina were declared divae before their funerals took place. ${ }^{2}$ This suggests a shift

\footnotetext{
* Published in The Classical Quarterly 69.1 (2019).

${ }^{1}$ E. Bickermann, 'Die römische Kaiserapotheosie', in A. Wlosok (ed.), Römischer
} Kaiserkult (Darmstadt, 1978), 82-121, at 100-106 (= Archiv für ReligionswissenschaftW 27 [1929], 1-31, at 15-19); id., 'Consecratio', in W. den Boer (ed.), Le culte des souverains dans l'empire romain. Entretiens Hardt 19 (Geneva, 1973), 1-37, at 13-25.

${ }^{2}$ L. Vidman, Fasti Ostienses (Prague, 1982²), 48 J 39-43: IIII k. Septembr. | [Marciana Aug] usta excessit divaq(ue) cognominata. | [Eodem die Mati]dia Augusta cognominata. III | [non. Sept. Marc]iana Augusta funere censorio | [elata est.], 49 O 11-14: X[— k. Nov. Fausti]na Aug[usta excessit eodemq(ue) die a] | senatu diva app [ellata et s(enatus) c(onsultum) fact] um fun[ere censorio eam efferendam.] Ludi et circenses [delati sunt. - i]dus N[ov. Faustina Augusta funere] | censorio elata $e[s t]$. Against this interpretation of the Marciana fragment (as published by A. Degrassi, Inscr. It. 13.1 [1947], 201) see E. Bickerman, 'Diva Augusta Marciana', 
away from the Augustan precedent, whereby the testimony of a (well-compensated) witness had been required to establish divinity (Suet. Aug. 100.4, Dio 56.46.2, 59.11.4, cf. Sen. Apoc. 1.2-3), to a procedure in which the senators were able to jump ahead to the politically foreordained conclusion and bestow the honour at once. ${ }^{3}$ Careful re-examination of the evidence in Tacitus (Ann. 12.69.3, 13.2.3) and Suetonius (Nero 9) has made it possible to assign this development to the year 54, with the consecration of Claudius. ${ }^{4}$

If the acceleration of the process suggests something about the shifting balance of power between the senate and the imperial family in the first century A.D., a delay might also be revealing. Certain postponements can be explained in terms of changing imperial priorities. For example, the twelve years it took for the empress Livia to become Diva Augusta can be attributed to the differing priorities of Tiberius, who initially refused divine honours on her behalf (Tac. Ann. 5.2.1), and her ultimate AJPh 95 (1974), 362-76; cf. J. H. Oliver, 'The Divi of the Hadrianic Period', HThR 42 (1949), 35-40, at 38 .

${ }^{3}$ F. Vittinghoff, Der Staatsfeind in der römishen Kaiserzeit: Untersuchungen zur ‘damnatio memoriae’ (Berlin, 1936), 77-80; J.-C. Richard, 'Incinération et inhumation aux funérailles impériales: Histoire du rituel de l'apothéose pendant le Haut-Empire', Latomus 25 (1966), 784-804, at 793-804; S. Price, 'From noble funerals to divine cult: the consecration of Roman Emperors', in D. Cannadine and S. Price (edd.), Rituals of Royalty: Power and Ceremonial in Traditional Societies (Cambridge, 1987), 56-105, at 91-3.

${ }^{4}$ W. Kierdorf, “"Funus" und "consecratio": zu Terminologie und Ablauf der römischen Kaiserapotheose', Chiron 16 (1986), 43-69, at 52-5; D. Fishwick, 'The Deification of Claudius', CQ 52 (2002), 341-9. 
benefactor Claudius, whom Suetonius portrays as especially dutiful in meeting the obligations of familial piety (Claud. 11.2: officia pietatis). The divinization of Pertinax was likewise postponed due to the usurpation of Didius Julianus, and so could not be put into effect until Septimius Severus' arrival in Rome (Dio 74.4-5, cf. SHA Pert. 14.9-15).

Vespasian, on the other hand, passed down his office to his own son in an orderly succession, and Titus obviously had much to gain from his father's consecration. Nevertheless, it appears that the founder of the Flavian dynasty faced a significant delay in becoming a god. As Buttrey demonstrated over four decades ago, the numismatic evidence suggests that divinity was not granted to Vespasian until sometime after the beginning of A.D. 80, when Titus and Domitian became consuls for the eighth and seventh times, respectively. ${ }^{5}$ Both are represented as having obtained this office before being identified as the son of a divus. ${ }^{6}$ This cannot be marked down to a failure on the part of the moneyers to attest filiation. The legends of Domitian's COS VII coins mark a clear progression, first styling the prince as

\footnotetext{
${ }^{5}$ T.V. Buttrey, 'Vespasian's Consecratio and the Numismatic Evidence', Historia 25 (1976), 449-57, recapitulated in id., Documentary Evidence for the Chronology of the Flavian Titulature (Meisenheim, 1980), 20 and 25; embraced by Kierdorf (n. 4), 65 n. 92; D. Kienast, Römische Kaisertabelle (Darmstadt, 1996), 108-9; B. Levick, Vespasian (London, 1999), 197. Contra: K. Scott, The Imperial Cult under the Flavians (Stuttgart, 1936), 40; G.W. Clarke, 'The Date of the Consecratio of Vespasian', Historia 15 (1966), 318-27.

${ }^{6}$ RIC $\mathrm{II}^{2} 205-13$, nos. 96-255.
} 
CAESAR AVG. F. DOMITIANVS before switching to some version of DIVI / DIVI AVG. / DIVI VESP. / DIVI AVG. VESP. F. at a later date. ${ }^{7}$

Epigraphy helps to narrow—but also complicates — the timeline. A military diploma from Bulgaria, in which the phrase divi Vespasiani f(ilius) makes its first appearance in Titus' official titulature, establishes 24-28 January, 80 as a plausible terminus ante quem. ${ }^{8}$ Taken together with the evidence of the coins, this should mean that Vespasian's consecration took place at some time in mid-January of 80 . There is, however, at least one inscription from Titus' seventh consulship in which he is described as divif(ilius). ${ }^{9}$ We must therefore settle for an absolute terminus post quem of 8 September, 79, marking the last secure date at which these terms were still absent

${ }^{7}$ RIC $\mathrm{II}^{2} 205$ nos. 96-9; RIC $\mathrm{II}^{2} 214-19$ nos. 265-355.

${ }^{8}$ CIL 16.158 = AE 1948.56; cf. RGZM 4. Not discussed by Buttrey ('Numismatic evidence', n. 5), 452, who cites the records of the Arval brethren for 29 May as the earliest datable testimony $(C I L 6.2059=$ Scheid, $C F A 48)$.

${ }^{9}$ CIL $6.1246=I L S 98 \mathrm{c}$. Buttrey (n. 5 [1976]), 456-7 suggests that this inscription may not have been set up until 80 , after the restoration project it refers to was completed. Why the emperor's filiation would have been updated but not his official titles remains unclear, however. Buttrey (ibid.), 450-2 is clearly right to discount $C I L$ 3.6732 (an editorial slip: see T.B. Mitford, 'New Inscriptions from Roman Cyprus', Opuscula Archaeologica 6 [1950], 1-95, at 85-7) and AE $1957.169=$ RIB 3.3123 (unreliably reconstructed) as evidence for apotheosis in 79 , but is perhaps too hasty in his dismissal of two inscriptions from Laodicea (IGR 4.845-6 = IK 49.15 and 9),

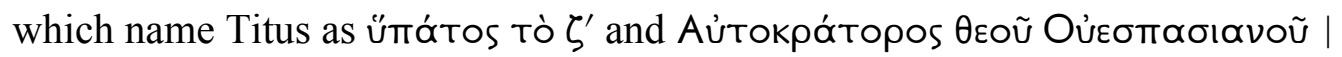

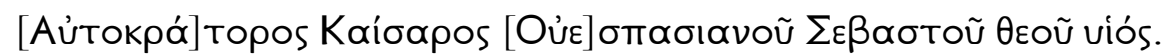


from Titus' official titulature. ${ }^{10}$ Vespasian was therefore not officially a divus — which is to say his children did not represent themselves as the sons of one-for at least 78 days following his death on 23 June (Suet. Vesp. 24). That is a longer delay than the one Pertinax had to endure.

This state of affairs requires explanation. It would be strange for Titus and Domitian to delay acknowledging their father's apotheosis if Vespasian had already attained this honour. The normal policy was for Imperial titulature to announce the divine status of an emperor's predecessor as soon as consecration was obtained. As noted above, there was a brief delay between Augustus' death on 19 August, A.D. 14 (Suet. Aug. 100.1) and his official consecration at the senate meeting following his funeral, on 17 September (Tac. Ann. 1.10.8). ${ }^{11}$ One inscription, which refers to Tiberius as Imp. Caes(ar) Augustif(ilius) Augustus, can be assigned to this interval $(C I L 8.10023=I L S 151)$. Tiberius is thereafter represented as divi Augusti f(ilius) in another inscription from the same year and on the first coins issued during his reign. ${ }^{12}$ Nero's status as a divi filius was advertised both numismatically and epigraphically without any apparent delay upon his accession to the throne in the middle of October, 54. ${ }^{13}$ This pattern continues after the Flavians as well, with the earliest datable

${ }^{10}$ CIL 16.24 = AE 1927.96; cf. RGZM 3. Buttrey (n. 5 [1976]), 452 also calls attention to $A E 1962.288$ (dated 7 September).

${ }^{11}$ Inscr. It. 13.2.25 = CIL 9.4192, p. 402; Inscr. It. 13.1.31 = CIL 10.6638, p. 664.

${ }^{12}$ CIL $2.4905=I L S 152 ;$ RIC $\mathrm{I}^{2} 93$ nos. 1-2.

${ }^{13} R I C \mathrm{I}^{2} 150$ nos. 1-3; IGR 4.1124 (A.D. 54); CIL $2.4719=I L S 225$ (A.D. 55). Unlike Tiberius, Nero would eventually abandon this emphasis on divine filiation: $R I C \mathrm{I}^{2}$ 153-85 nos. 44-606; cf. Suet. Nero 33.1; Dio 60.35.2-4; O. Hekster, Emperors and Ancestors (Oxford, 2015), 51-2. 
inscriptions of every emperor from Trajan down to Commodus attesting to his status as the son of a deified predecessor. ${ }^{14}$ The main difference is that patronymic formulae are generally absent from the coinage of the second century, which makes it more difficult to date the commemoration of Imperial consecrations in this medium. ${ }^{15}$ As the lone exception to this trend, Hadrian is duly styled DIVI. TRAIAN. AVG. F. and sometimes also DIVI NER. NEP. on his first emissions of 117 , however. ${ }^{16}$

There is every reason to suppose that the Flavians would have been eager to see the founder of their dynasty elevated to divine status as soon as possible. If such proof was even necessary, the appearance of a comet in late March and April of 79

${ }^{14} A E 1990.131 \mathrm{c}, \mathrm{e}=C I L 10.6820,6826,6824 ; C I L 2.4685,12.4341,16.42 ; A E$ 1949.42 (Trajan, A.D. 98). IGR 4.349 (Hadrian, A.D. 117); also CIL 2.429; IG 12.3.175-6 (A.D. 118). $A E$ 1914.174; CIL 2.4057; CIL 9.697 = ILS 332; CIL $6.999=$ ILS 333; CIL 14.4357 (Pius, A.D. 138 - perhaps predating Hadrian's official consecration? cf. n. 26 below). CIL $6.31554=I L S$ 5933; CIL 3.208, 3744, 6.40867-8, 10.1647 (M. Aurelius and L. Verus, A.D. 161). CIL 8.23828; $A E 1938.131$

(Commodus, A.D. 181). See in general M. Hammond, The Antonine Monarchy (Rome, 1959), 203-7.

${ }^{15}$ It was during this period that 'consecration' series commemorating the deification of members of the emperor's family become common: RIC II $^{1} 299-301$ nos. 743-64; 390-1 nos. 418-27; 479 nos. 1051-2; RIC III 69-76 nos. 343-407; 161-9 nos. 10991200; 247 nos. 429-42; 441 nos. 654-64. Titus' undated DIVVS AVGVSTVS VESPASIANVS coins (RIC II $^{2} 219-21$ nos. 356-84) may be regarded as a precursor of this development.

${ }^{16}$ RIC II $^{1} 338-40$ nos. 2-16. 
appears to have been interpreted as a harbinger of Vespasian's eventual apotheosis. ${ }^{17}$ His deathbed quip, 'vae, puto deus fio' also suggests that divinization was anticipated during his lifetime. ${ }^{18}$ Titus did ultimately issue extensive series of coins in both precious metals and bronze celebrating DIVVS AVGVSTVS VESPASIANVS on the obverse, thus demonstrating that he understood the ideological usefulness of divine parentage. ${ }^{19}$ His motivations were apparent to Pliny the Younger, at least, who provides a brief history of imperial apotheoses when discussing Nerva's divinization in the Panegyricus (11.1-2).

The passage requires quoting in full:

Dicavit caelo Tiberius Augustum, sed ut maiestatis crimen induceret; Claudium Nero, sed ut irrideret; Vespasianum Titus, Domitianus Titum, sed ille ut dei filius, hic ut frater videretur. Tu sideribus patrem intulisti non ad

${ }^{17}$ Suet. Vesp. 23.4; cf. Dio 66.17.2-3. The precise dating of this comet is preserved in the Samguk Sagi, a medieval Korean chronicle: see P. Kim (trans. E.J. Shultz and H.W. Kang), The Silla Annals of the Samguk Sagi (Seongnam, 2012), 43; J.T. Ramsey, A Descriptive Catalogue of Greco-Roman Comets from 500 B.C. to A.D. 400 (Iowa City, 2006), 161-3.

${ }^{18}$ Suet. Vesp. 23.4 ('alas, I think I am becoming a god'); D. Fishwick, 'Vae puto deus fio', CQ 15 (1965), 155-7; pace M.G. Schmidt, 'Claudius und Vespasian: Eine neue Interpretation des Wortes “vae, puto, deus fio” (Suet. Vesp. 23, 4)', Chiron 18 (1988), 83-9. Note also Pliny the Elder's prediction (HN 2.18) that the eternal glory of divinity awaited Vespasian as a reward for his services to humanity.

${ }^{19}$ RIC II $219-21$ nos. 356-84 (undated). 
metum civium, non in contumeliam numinum, non in honorem tuum, sed quia deum credis.

Tiberius declared that Augustus was divine, but in order to justify charges of treason. Nero did this with Claudius, but in order to mock him; Titus did this with Vespasian, and Domitian Titus, but one in order to appear as the son of a god, the other as the brother of one. You (sc. Trajan) raised your father to the stars not to terrorize citizens, nor in contempt for the divine, nor for your own honour, but because you believe him to be a god.

For Pliny, the actions of Tiberius and Nero represent a stark dichotomy: divinization of one's father could lead either to an expansion of the crimen maiestatis (as insults to such deities were made liable to prosecution) or to a devaluing of the gods altogether (when the new emperor condoned and even participated in such insults). ${ }^{20}$ Pliny has obviously simplified matters in order to more effectively praise Trajan's supposed pietas,${ }^{21}$ but what stands out as relevant for the present argument is the apparent ease

${ }^{20}$ See R.A. Bauman, Impietas in Principem: A study of treason against the Roman emperor with special reference to the first century A. D. (Munich, 1974), 16-17, 7182.

${ }^{21}$ Tacitus presents Tiberius as initially reluctant to pursue treason charges stemming from insults to Augustus' divinity, paraphrasing a letter to the consuls in which he warned, 'the heavens had not been decreed for his father so that this honour could be turned into a civil menace' (non ideo decretum patri suo caelum, ut in perniciem civium is honor verteretur, Ann. 1.73.3). As with so much in the historian's account of this emperor, however, Tiberius' resistance is presented to the reader as a ruse, 
with which he exempts the Flavian apotheoses from this trade-off, such that vainglory becomes the only motivation for Titus and subsequently Domitian.

How this transformation might have been accomplished is suggested by Cassius Dio, who is quoted by Xiphilinus as having Titus declare, 'those emperors who have passed on, if they are truly divine and have such power, will avenge themselves if anyone should injure them' (66.19.2: oi $\delta \dot{\varepsilon} \mu \varepsilon т \eta \lambda \lambda \alpha \chi o ́ T \varepsilon s ~ T \tilde{\omega} \nu$

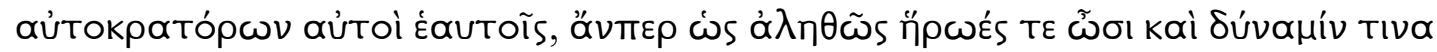

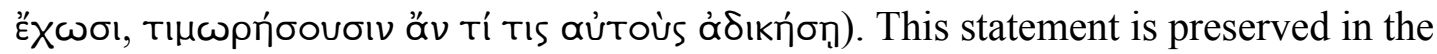
context of a discussion of the remarkable fact that no senators were killed, either by the emperor or any other agent, during Titus' brief reign (cf. Dio 67.2.4). Although sometimes associated with the 'oath not to put senators to death' that all 'good' emperors (and those who wished to appear as such) subsequently offered at the outset of their reigns, this comment, which follows Titus' disavowal of retribution for criticisms of himself, is in fact part of a more narrowly crafted justification of a

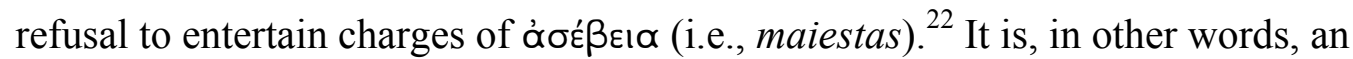
prefaced by a caveat that this initial impediment did nothing to prevent the charge from catching fire and eventually overwhelming everything (quanta Tiberii arte gravissimum exitium inrepserit, dein repressum sit, postremo arserit cunctaque corripuerit, 1.73.1). The issue of Claudius' divinity under Nero is considerably more complicated: see M. Griffin, 'Claudius in the Judgement of the Next Half-Century', in V.M. Strocka (ed), Die Regierungszeit des Kaisers Claudius (41-54 n. Chr.): Umbruch oder Episode? (Mainz, 1994), 307-16; J. Osgood, Claudius Caesar: Image and Power in the Early Roman Empire (Cambridge, 2011), 245-56.

${ }^{22}$ Cf. Suet. Tit. 9.1: periturum se potius quam perditurum adiurans ('swearing he would rather perish than destroy'); A.R. Birley, 'The Oath Not to Put Senators to 
explicit rejection of the Tiberian precedent, and an assurance that Vespasian's divinity would not become a pretext for trials and executions.

It is not difficult to imagine that some members of the senate would have sought such an assurance from Titus, and possibly even delayed Vespasian's consecration in order to obtain it. As praetorian prefect under his father, Titus had operated with brutal efficiency to eliminate perceived threats to the regime, but he significantly damaged his reputation in the process. ${ }^{23}$ Wary of a potential second Nero, many senators were no doubt reluctant to create a state of affairs they knew could be exploited to destroy anyone suspected of disloyalty. We are told that the senate was prepared to withhold divine honours from Hadrian in 138, so it is not inconceivable that this option was also available to them at the beginning of Titus' reign. ${ }^{24}$ Resistance to Vespasian's divinization would have posed a significant Death', CR 12 (1962), 197-9; Bauman (n. 22), 214-17; also Levick (n. 5), 198. Subsequent vows: Dio 68.2.3, 68.5.2, 69.4.4, 73.5.2, 74.2.1: oĩa kai oi mpफ́nv áyaӨoì aútokpátopes. See esp. P. Garnsey, Social Status and Legal Privilege in the Roman Empire (Oxford, 1970), 44-9.

${ }^{23}$ Suet. Tit. 6.1-2; Dio 66.16.3-4. C.L. Murison, 'The Emperor Titus,' in A. Zissos, (ed.), A Companion to the Flavian Age of Imperial Rome (Malden, MA, 2016), 76-91, at $86-7$.

${ }^{24}$ Dio 69.23.3; SHA Hadr. 27.2, Antonin. 2.5; Aur. Vict. 14.13-14. A delay of at least a year is suggested by the titulature in Hadrian's epitaph, CIL $6.984=I L S 322$ (but cf. n. 16 above): A. Chastagnol, 'Un chapitre négligé de l'épigraphie latine: la titulature des empereurs morts', REL 62 (1984), 275-287, at 285. On the significance of the senate's role, see Price (n. 3), 82-91; G. Bonamente, 'Il Senato e l'apoteosi degli imperatori da Augusto a Teodosio il grande', in K. Rosen (ed.) Macht und Kultur im 
stumbling-block to the Flavians' celestial ambitions, but could conceivably have prompted a debate over the nature of this honour and its legal ramifications. Titus' concession that those 'who have passed on' should be left to tend to their own vengeance would then represent the result of an extended negotiation, which would mean that the delay in Vespasian's consecration can be regarded as evidence of the senate's capacity to act with some measure of independence in order to assert its own interests at this time.

Rom der Kaiserzeit (Bonn, 1994), 137-64. Note also Dio 59.3.7 on the senate's ambivalent response to Gaius' request for posthumous honours for Tiberius. 